solubility of the calcium salts of the three acids in alcohol of varying concentration.-F. L. Navarro: The non-existence of the Cretacean in the island of Hierro (Canaries). The author, after visits to the island of Hierro in I9II and IgI7, has definitely proved the absence of Crataceous deposits. The fossil, Discoidea pulvinata, described by $\mathrm{J}$. Cottreau and P. Lemoine in I9Io, was probably brought to the island by a ship as ballast. $-\mathrm{F}$. Georgévitch : The evolutive cycle of $M y x i-$ dium gadii.-A. Lécaillon: Aptitude for natural parthenogenesis considered in various races or varieties of the silkworm.-L. Boutan : The role of the fins in teleostean fishes with swimming bladder.-W. Kopaczewski : The mechanism of the toxic action of the serum of the muræna.

\section{CAPE Town}

Royal Society of South Africa, October 17, I9I7--Dr. A. Jasper Anderson, vice-president, in the chair.-J. Moir : Spectrum phenomena in the chromium compounds, being part iv. of the spectrum of the ruby and emerald. It has been found that although aqueous solutions of the chromium salts do not show any narrow characteristic bands in the spectrum, yet when anhydrous (or nearly anhydrous) solutions are used the spectrum is crossed by narrow bands in the red similar to what are seen in the ruby or emerald spectrum. The solutions of chromium oxide in concentrated sulphuric and in fused metaphosphoric acid have been investigated, and the bands measured; they are very similar to those seen in the emerald, but not absolutely identical; while the bands of the ruby, although similar in arrangement, are displaced into a region of lower frequency. Both gem colours are due to chromium, but the vibrations are differently loaded (silica and beryllia against alumina).-J. Moir : Colour and chemical constitution Part iii.: Derivatives of the unknown ortho-para-phenolphthalein. Phthaleins in which one of the hydroxyl groups is ortho- and the other para- to the central carbon have been prepared from para-substituted phenols with oxybenzoylbenzoic acid. They are like the common phthaleins, but their absorption bands are broad, although in much the same position.

\section{BOOKS RECEIVED.}

The University of Sheffield. Calendar for the Session 1917-18. Pp. 767. (Sheffield: The University.)

Medicinsk-Historiske Smaaskrifter. 18. Om Lægekunst Hos Perserne. By A. Christensen. (København : Vilhelm Trydes Forlag.)

The Education of Engineers. By H. G. Taylor. Pp. vii +64. (London: G. Bell and Sons, Ltd.) 2s. net.

Chemistry for Beginners. By C. T. Kingzett.

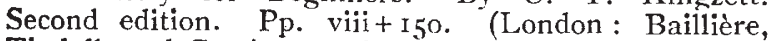
Tindall, and Cox.) 2s. $6 d$. net.

Les Universités et. la Vie Scientifique aux EtatsUnis. By Prof. M. Caullery. (Paris : A. Colin.) 3.50 francs.

\section{DIARY OF SOCIETIES.}

RoYar Institution, THURSDAY. JANUARY 2.

RoYAz INSTITUTInN, at 3.-Electricity as an Illuminator and Doctor: Prof. J. A. Fleming.

Chrld Study Association, at 5.30.-Dischession: The Education of the Clever Child: Openers: G. F. Daniell and Miss M. Berryman.

Association of Science TrFachers (University College, Gower Street), at 1r:3o:- Some Applications of Physics: Prof. Dovidge.-At 2.30.
Discussion: The Teaching of Physics in Girls' Schools : Opener: Prof. F. Womack.

$$
\text { SATURDAY, JANUARY } 5 \text {. }
$$

Roval I vstítution, at 3.-Electric Dynamos; Motors, Transformers, and Railways : Prof. J.A. A. Fleming.

Grographical. Association, at ir.30.-The Crafts of Britain, Past and Future: H. Wilson.-At 3.-Map Study in Geography and Military NO. 25 I 4 , VOL. IOO]
MONDAY, JANUARY 7 .

Society of Chemical Industry, at 8.-The Toxicity of Methyl Alcohol in Relation to its Industrial Uses. A Review of the Published Data: T. D. Morson.-The Rapid Estimation of Pyridine in Ammonia: T. F. Harvey and C. F. Sparks. - (I) Corrosion of Lead Roofing; (2) The Action of Rainwater on a Portland Stone : Prof. J. S. S. Brame.

Gengraphicai. Association (London Day Training College), at Jo.30.Discussion: Geography in Advanced Courses: (jpeners: Miss Odell L. Brooks, and W. H. Barker.-At 5 (King's College).--Presidentia ARIstotelian Society, at 8.-Is there a Mathematics of Intensity?: Prof. J. A. Smith.

Royal Geographicai Society (Kensington Town Hall), at 3.30.-The Yuikon since the Trail of ' 98 : Mrs. George Black.
Yuity TUESDAY, JANUARY 8.

Association of Public School Science Masters (City of London School) at 12.15.-President's address:- The Needs of our Education at the Presen Day, with Special Reference to Science Teaching.-At 3.-Discussion. Compulsory Science in University Entrance Examinations: Opener O. H. Latter.-At 3.45.-Discussion: Examination or Inspection as a Test of Science Teaching: Opener: G. F. Daniell.--At 5.15.-Discussion? Subsidiary Subjects in University Scholarship Examinations: Opener H. de Havilland.

Royal Instirution, at 3.-Electric Telegraphs and Telephones: Prof J. A. Fleming.

InSTITUTION OF CIVIL ENGINEERS, at 5.30.-A Statement in Commemoration of the Founding lof the Institution on January 2, $1818 .-$ Rail-Creep: F. Reeves.-Creep of Rails: H. P. Miles.

WEDNESDAY, Januarv 9.
association of Public School Science Masters (City of London School), at ir.-Discussion: "Descriptive Astronomy" in the "Science for All" Course: Openers: Rev. A. L. Cortie, S.J., E. O. Tancock.for All" Course: Openers: Rev, A. L. Cortie,

At $12 .-$ Discussion: "Map Work" in Schools.
Mathematical Association (London Uay Training College), at $5.30 .-$ The Graphical Treatment of Power Series : Dr. W. P. Milne.

Geological. SocIEv' at $5 \cdot 30$. The Highest Silurian Rocks of the Clun Forest District (Shropshire): L. D. Stamp. THURSDAY, JANUARY IO

InStitution of EleCtrical ENGineERs; al 6.-Electrical Signalling and Control on Railways: C. M. Jacobs.

Mathematical Association (London Day Training College), at IrThe Uses and Functions of a.School Mathematical Library: Dr. W. P. Milne.-Nomography : Dr. S. Brodetsky.- Some. Suggestions for a Presentment of Mathematics in Closer Touch with Reality: G. Goodwill. At 2.30.- President's address: Mathematicr and Individuality: Prof. T.P the Board of Education for Secondary Schools: Openers: W, D. Eggar, P. Abbott, Miss J. Dow.

FRIDAY, JANUARY II.

Royal Geographical Society (Kensington Town Hall), at 3.30.-The OId Life in Egypt: Miss Mary Brodrick.

ROYAL Astronomical Society, at 5 .

\section{CONTENTS.}

PAGE

Electrical Engineering. By Dr, A. Russell . . . . $34 \mathrm{I}$ Geodetic Base Measurements. By H. G. L. . . . 342 Philosophy . . . . . . . . . . . 342

Our Bookshelf . . . . . . . . . . . 343

Letters to the Editor:-

Magnetic Storm and Aurora, December I6-I7.-Dr.

C. Chree, F.R.S.

Sources of Potash. By Sir T. E. Thorpe, C.B.,

$\mathbf{F}, \mathbf{R} \mathbf{S}$.

National Power Supply * . . . . . . . . 344

Economising Sugar . . . . . . . . . . . . . . 347

Notes . . . . . . . . . . . . . . . 348

Our Astronomical Column :-

New Stars in Spiral Nebulæe . . . . . . . . $35 \mathrm{r}$

"Companion to the Observatory for 1918"..... 351

Hyderabad Observatory Report . . . . . . 35 I

Prize Awards of the Paris Academy of Sciences, I9r 7352

Committee on the Chemical Trade . . . . . . . 353

The Physiology of Learning . . . . . . . . . 353

International Fishery Statistics. By J. J. . * * * 354

The Production of Scientific Knowledge. (With

Diagrams.) By Dr. C. E. Kenneth Mees. . . . . 355

University and Educational Intelligence . . . . . 358

Societies and Academies . . . . . . . . . . 359

Books Received . . . . . . . . . . . . . . 360

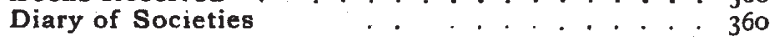

Editorial and Publishing Offices:

MACMILLAN AND CO., LTD.,

ST. MARTIN'S STREET, LONDON, W.C.2.

Advertisements and business letters to be addressed to the Publishers.

Editorial Communications to the Editor.

Telegraphic Address: Phusis, London.

Telephone Number: GERRARD 8830. 